\title{
One Step RT-PCR Method for Quick and Reliable Detection of Citrus tristeza virus (CTV) in Mid-Hills of Meghalaya, India
}

\author{
T. Ganesh ${ }^{1 *}$, T. Rajesh ${ }^{1}$, A. Banerjee ${ }^{2}$ and H. Rymbai ${ }^{2}$ \\ ${ }^{1}$ College of Post Graduate Studies, CAU, Umiam-793103, Meghalaya, India \\ ${ }^{2}$ ICAR RC for NEH Region, Umiam-793103, Meghalaya, India \\ *Corresponding author
}

\section{A B S T R A C T}

\section{Keywords}

CTD, CTV, Closterovirus RTPCR, Edbr

Article Info

Accepted:

12 April 2018 Available Online:

10 May 2018
Citrus tristeza disease (CTD) is the most dangerous and lethal viral disease among all the viral diseases that attack to the citrus. It is caused by Citrus tristeza virus (CTV) belongs to the genus Closterovirus in the family Closteroviridae. For quick and reliable detection of CTV a one-step RT-PCR technique was standardised. The total RNA from the leaf sample was extracted by using the Quiazen RNAeasy plant mini kit. The RT-PCR kit was used for the RT-PCR reaction and the primers specific to the coat protein component of the virus is used for detection. The PCR products were subjected to the gel electrophoresis on the $1 \%$ agarose gel containing $2.5 \mathrm{ug}$ of ethidium bromide (Edbr). After gel running these products are visualized under UV transilluminator. Where the CTV positive samples yield an amplicon of 672 bps but where as in negative samples there was no such amplicon. Therefore the standardized RT-PCR is found to be most sensitive and reliable method for quick detection of $\mathrm{CTV}$ in the infected samples.

\section{Introduction}

Citrus tristeza virus (CTV) is the most important viral pathogen under the genus Closterovirus in family Closteroviridae and the members of this family are characterized by the long, flexuous and thread like particles with $10-12 \mathrm{~nm}$ x $2000 \mathrm{~nm}$, having a single stranded positive sense RNA as genome (monopartite) which comprises about 19,256 nucleotides (Karasev et al., 1995) with 12 ORF'S encoding at least 19 proteins (BarJoseph and Dawson, 2008) and about $95 \%$ of the genome of CTV is encapsidated by the 25 $\mathrm{kDa}$, considered as major CP (Febres et al., 1996; Ahlawat and Pant, 2003). CTV is the longest plant virus among all plant viruses (Yokomi, 2011) and it next to genome of animal Coronaviruses, the largest known genome worldwide (Albiach-Marti, 2013). CTV is not a seed (McClean, 1957) or pollen borne virus (Moreno et al., 2008). It is a phloem limited virus, mostly transmitted by grafting and insect vector citrus brown aphid (Toxoptera citricida; Kirkaldy), (Michaud, 1998; Moreno et al., 2008; Gottwald, 2010) and black aphid (Toxoptera auranti) (Yokomi and Garnsey, 1987; Hermoso et al., 1984) in a semi-persistent manner (McClean, 1957).

Both nymphs and adults of the aphids were found to capable transmission of virus 
(Yokomi and Garnsey, 1987). While the transmission efficiency can vary from one isolate to the other isolates of virus. In general host range of CTV is restricted to plant species of the genera Citrus, Poncirus (a citrus relative which is widely used as a rootstock) and Fortunella (subfamily Aurantioidae, family Rutaceae) (Moreno et al., 2008). The virus shows greatest diversity in terms of its genetic and biological properties and it causes various kinds of symptoms on host plant like stunting, seedling yellowing or chlorosis, vein clearing, vein flecking, vein corcking, stem pitting, slow decline, quick decline all associated with the disruption of the phloem tissue and its functions (Lee and Blansky, 1989: Roistacher and Moreno, 1991; Kashyap et al., 2013) or no symptoms depending on the virus strain, citrus cultivar, root stock, time of infection and environmental conditions (Lee and Rocha- Pena, 1992).

\section{Materials and Methods}

The CTV suspected leaf samples were collected from the citrus orchards in mid-hills of Meghalaya and these field collected samples were brought to the laboratory for further confirmation of the virus by using the molecular tools like RT-PCR. The presence of the CTV was confirmed through Reverse Transcription- Polymerase chain reaction (RTPCR) using primers specific to Coat protein gene $(\mathrm{CPg})$ component of the virus. First the total RNA from the leaf tissue was extracted by using the QIAGEN RNeasy Plant Mini Kit by following the manufactures protocol. The RT-PCR reaction was carried out by using the total RNA as template and one-step RT-PCR kit, where it contains the different components like one step RT-PCR buffer containing 12.5 $\mathrm{mM} \mathrm{Mgcl}_{2}, 10 \mathrm{mM}$ dNTP-mix, One step RTPCR enzyme mix $1 \mu \mathrm{l} /$ reaction and RNase free water. The RT-PCR amplifications were carried out in thermal cycler (AB applied Biosystems, Life technologies, Singapore).
The reaction mixture contained $1 \mu \mathrm{l}$ of total RNA, $1 \mu \mathrm{l}$ each of $10 \mu \mathrm{M}$ forward and reverse primers, $5 \mu \mathrm{l}$ of $5 \mathrm{X}$ one step RT-PCR buffer, containing $2.5 \mathrm{mM} \mathrm{MgCl}_{2}, 1 \mu \mathrm{l}$ of $10 \mathrm{mM}$ dNTPs, $1 \mu$ of one-step RT-PCR enzyme mix and RNase free water to make up volume up to $25 \mu$ l. RT-PCR cycles were composed of an initial Reveres transcription step at $50{ }^{\circ} \mathrm{C}$ for 30 min followed by an initial PCR activation at $95{ }^{\circ} \mathrm{C}$ for $15 \mathrm{~min}$, followed by 30 cycles of denaturation at $94{ }^{\circ} \mathrm{C}$ for $30 \mathrm{sec}$, annealing at $60{ }^{\circ} \mathrm{C}$ for $1 \mathrm{~min}$ and extension for $1 \mathrm{~min}$ at 72 ${ }^{\circ} \mathrm{C}$. A final extension was allowed for $10 \mathrm{~min}$ at $72{ }^{\circ} \mathrm{C}$. The amplified products were subjected to electrophoresis on 1\% agarose gel containing $2.5 \mu \mathrm{l}$ of Ethidium bromide. Then the amplified products were loaded into the wells by mixing with loading dye (final concentration $1 \mathrm{X}$ ) along with the $1 \mathrm{~kb}$ DNA ladder as a marker and the gel was run for $1 \mathrm{hr}$ at a fixed voltage $(7 \mathrm{~V} / \mathrm{cm})$. The gel was examined in a UV trans-illuminator (GelDoc XR, Biorad, Germany) and photographed. The presence of CTV was confirmed with the presence of $672 \mathrm{bp}$ amplicon, but where as in healthy samples there was no such amplicon.

\section{Results and Discussion}

The yellowing, vein clearing, vein corking symptoms were observed on the plants in the orchards during the sample collection (Fig. 1). In some plants they did not show any such type of symptoms, even though they were infected with the CTV i.e., latent infection. But during this study, any aphid vectors (Toxoptera citricida) as well as the stem pitting symptom related to CTV infection on khasi mandarin plants, were not noticed in the plants. Detection of CTV was carried out through (RT-PCR) by using primers specific to the coat protein gene of the virus. The extracted total leaf RNA (template) from each sample was assayed. In CTV positive samples, the RT-PCR amplicon of $\sim 672 \mathrm{bp}$ corresponding to the full length of coat protein 
was amplified, where as in healthy samples such amplification was absent (Fig. 2). The results from RT- PCR assay confirmed the occurrence of CTV in field collected samples. During the survey, Citrus tristeza virus incidence in affected orchards was recorded as 30-70 \% based on symptomatology. At least 6-7 plants with yellowing, vein clearing like symptom related to CTV was observed in during sample collection.

The presence of CTV was confirmed with the presence of $672 \mathrm{bp}$ amplicon

\begin{tabular}{lcrc}
\hline Primers & Sequence (5'-3') & $\begin{array}{c}\text { Working } \\
\text { Concentration }\end{array}$ & $\begin{array}{c}\text { Annealing } \\
\text { temperature (Tm) }\end{array}$ \\
\hline$\underline{\text { CP-gene }}$ & & & \\
Fp $\quad$ 5' CTCTAGATCTTTTGAATTATGGACGAC 3' & $10 \mu \mathrm{M}$ & \\
Rp $\quad$ 5' CGCGAATTCAACAGATCAACGTGTGT 3' & $10 \mu \mathrm{M}$ & $60^{\circ} \mathrm{C}$ \\
\hline
\end{tabular}
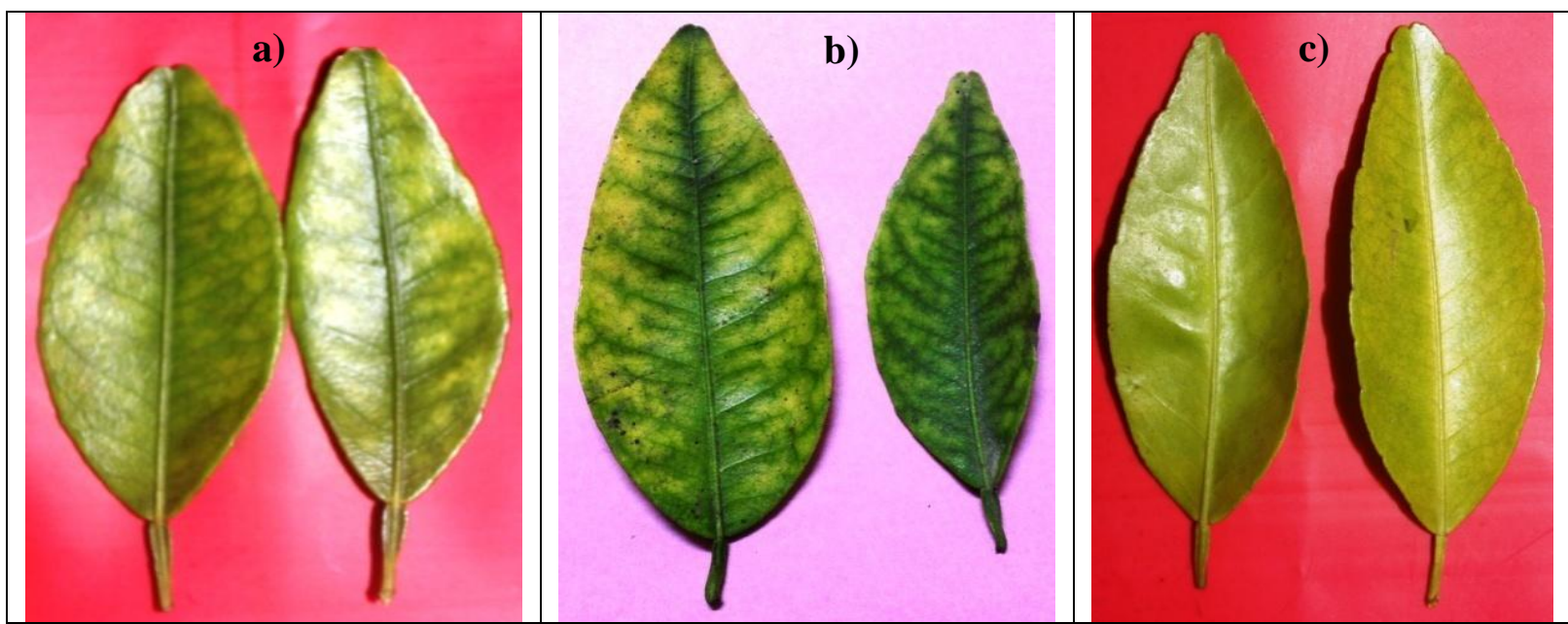

Fig.1 CTV Suspected samples collected from the different orchards (a. Amlarem; b. Bawrywmbong; c. Umiam) in the Mid hills of Meghalaya

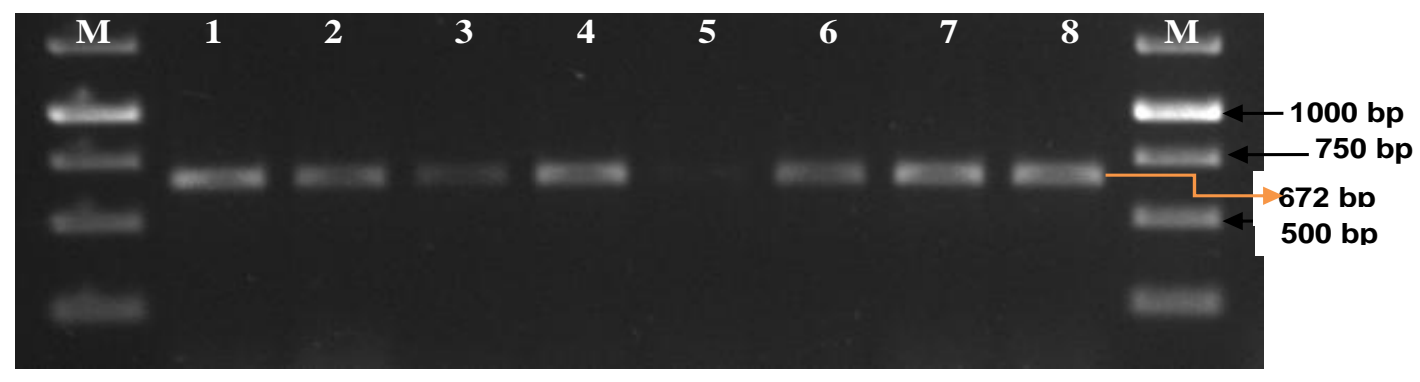

Fig.2 RT- PCR based detection of CTV using the Coat protein (CP) gene specific primers. Presence of CTV was confirmed by an amplication of $672 \mathrm{bp} . \mathrm{M}=1 \mathrm{~kb}$ ladder as a marker; Lane 1-4 \& 7, 8 field collected samples. Lane 5- Negative control; Lane-6 Positive control. 
In the present study the one step RT-PCR method detected the CTV in the field collected samples from the Mid-hills of Meghalaya. The RT- PCR also detected the CTV in latent infected samples where these samples do not show the any kind of CTV symptoms in the orchards. The earlier researchers Hung et al., (2000), also used the rapid and sensitive method, one-step RT-PCR technique for detection of CTV this method combines the reverse transcription (RT) and polymerase chain reaction (PCR) in one tube using an optimized buffer condition and efficient enzyme mix. Similarly Latanya et al., (2010) detected the CTV in grape fruit, sweet orange and sour orange orchards in Jamaica by using the RTPCR assay.

Nikolaeva et al., (1995) and Kim et al., (2000) were detected the severe isolates of CTV in California and Satsuma mandarin (Citrus unshiu) in Korea and in mandarin from Darjeeling hills in India. Hung et al., (2000) also used the RT-PCR for differentiating CTV isolates into decline inducing or non- decline inducing in CTV infected field trees in Florida. In comparison with the two-step RT-PCR and ELISA tests the one step RT-PCR method has high sensitivity in CTV detection especially when CTV concentration is low in its host. Harper et al., (2009) also used both one step and two-step reverse transcription-polymerase chain reaction (RT-PCR) for the detection of CTV in New Zealand. Gillings et al., (1993) used the RT-PCR by using a one-step RT-PCR kit (QIAGEN) by following the manufacturers protocol. RT-PCR thermo cycling conditions followed were one cycle at $50^{\circ} \mathrm{C}$ for $30 \mathrm{~min}$, one cycle at $94^{\circ} \mathrm{C}$ for $2 \mathrm{~min}$, followed by 35 cycles at $94^{\circ} \mathrm{C}$ for $30 \mathrm{~s}, 52^{\circ} \mathrm{C}$ for $30 \mathrm{~s}$ and $72^{\circ} \mathrm{C}$ for $60 \mathrm{~s}$ and a final extension at $72^{\circ} \mathrm{C}$ for $10 \mathrm{~min}$. Amplified products were detected in a $1 \%$ agarosegel in 1xTBE buffer, stained with Ethidium bromide and visualised on a ultraviolet transilluminator. The one step RTPCR standardized in this study can be useful for the reliable and sensitive tool for quick detection of CTV in latent infections and as well as in CTV infected samples where the virus concentration is low. This RT-PCR was found to be good molecular based tool for quick detection of CTV in the infected samples.

\section{References}

Ahlawat, Y.S. and Pant, R.P. (2003). Major virus and virus-like diseases of citrus in India, their diagnosis and management. Ann. Rev. Plant Pathol., 2: 447-474.

Albiach-Marti, M.R. (2013). The Complex Genetics of Citrus tristeza virus, Current Issues in Molecular Virology- Viral Genetics and Biotechnological Applications, http://dx.doi.org/10.5772/56122.

Bar-Joseph, M. and Dawson, W.O. (2008). Citrus tristeza virus. Encyclopedia of voirology., pp. 520-525.

Febres, V. J., Ashoulin, L., Mawassi, M., Frank, A., Bar-joseph, M., Manjunath, K. L., Lee, R. F., and Niblett, C. L. (1996). Protein is present at one end of citrus tristeza virus particles. Phytopathology., 86: 1331-1335.

Gillings, M., Broadbent, P., Indsto, J., and Lee, R. F. (1993). Characterization of isolates and strains of citrus tristeza closterovirus using restriction analysis of the coat protein amplified by the polymerase chain reaction. J. Virol. Methods., 44: 305-317.

Gottwald, T.R. (2010). Concepts in the epidemiology of Citrus tristeza virus In: Citrus tristeza virus complex and Tristeza diseases, Karasev AV and Hilf ME (Eds), APS Press, St Paul, MN, USA, pp. 119131.

Harper, S. J., Dawson, T. E., and Pearson, M. N. (2009). Complete genome sequences of two distinct and diverse Citrus tristeza virus isolates from New Zealand. Arch Virol., 154: 1505-1510.

Hermoso de Mendoza, A., Ballester-Olmos, J.F. and PinaLorca, J.A. (1984). Transmission of Citrus tristeza virus by aphids (Homoptera, Aphididae) in Spain In: Proceedings of the 9th Conference of the International Organization of Citrus Virologists, Garnsey SM, Timmer LW 
and Dodds JA (Eds), IOCV. Pp23-27, Riverside. CA, USA.

Hung, T. H., Wu, M. L., and Su, H. J. (2000). A rapid method based on the one-step reverse transcriptase-polymerase chain reaction (RT-PCR) technique for detection of different strains of Citrus tristeza virus. J. Phytopathol., 148: 469475.

Karasev, A.V., Boyko, V. P., Gowda, S., Nikolaeva, O.V., Hilf, M.E., Koonin, E.V., Nilbett, C. L., Cline, K., Gumpf, D.J., Lee, R.F., Garnsey, S. M., and Dawson, W.O. (1995). Complete sequence of Citrus tristeza virus RNA genome. Virol., 208: 511-520.

Kashyap, Anurag., Acharjee, S., and Nath, P.D. (2013). Serological and Molecular detection of in Citrus fruit species of north eastern region of India. $J$ Mycol Plant Pathol., 43(4): 431-435.

Kim, D., Hyun, J., Hwang, H., and Lee, S. (2000). RT-PCR Detection of Citrus Tristeza Virus from Early Satsuma mandarin and Yuzu in Cheju Island. Plant Pathol. J., 16(1): 48-51.

Latanya, C., Fisher-Paula, F., Tennant-Wayne, A., and McLaughlin. (2010). Detection and characterization of Citrus tristeza virus stem pitting isolates in Jamaica. Eur J Plant Pathol., 127: 1-6.

Lee, R.F. and Brlansky, R. H. (1989). Variation in the severity of Citrus tristeza virus isolates from groves with quick decline. In: proc. Florida State Hort Soc., 102:13.

Lee, R.F. and Rocha-Pena, M.A. (1992). Citrus tristeza virus, p. 226-249. In: Plant Diseases of international Importance. Diseases of Fruits Crops. J Kumar, S
Chaube, US Singh and A N Mukhopadhay (Eds). Prentice Hall, Eanglewood Cliffs, N.J. 3: 456.

McClean, A.P.D. (1957). Tristeza virus of citrus: evidence for absence of seed transmission, Plant Dis. Reporter., 41: 821.

Michaud, J.P. (1998). A review of the literature on Toxoptera citricida (Kirkaldi) (Homoptera: Aphididae). Florida Entomologist., 81(1): 37-61.

Moreno, P., Ambros, S., Albiach-Marti, M.R., Guerri, J., and Pena, L. (2008). Citrus tristeza virus: a pathogen that changed the course of the citrus industry. Mol. Plant Pathol., 9(2): 251-268.

Nikolaeva, O.V., Karasev, A.V., Gumpf, D.J., Lee, R.F., and Garnsey, S.M. (1995). Production of polyclonal antisera to the coat protein of Citrus tristeza virus expressed in Escherichia coli: application for immunodiagnosis. Phytopathology., 85: 691-694.

Roistacher, C. N. and Moreno, P. (1991). The worldwide threat from destructive isolates of Citrus tristeza virus. A review. In Proceedings of the 11th Conference of the International Organization of Citrus Virologists. University of California Riverside: Pp. 7-19, California Riverside.

Yokomi, R.K. (2011). Etiology, background, worldwide situation and control of Citrus tristeza virus and its vectors, 2nd International workshop on citrus quarantine pest, Mexico.

Yokomi, R.K. and Garnsey, S.M. (1987). Transmission of Citrus tristeza virus by Aphis gossypii and Aphis citricola in Florida. Phytophylactica., 19: 169-172.

\section{How to cite this article:}

Ganesh, T., T. Rajesh, A. Banerjee and Rymbai, H. 2018. One Step RT-PCR Method for Quick and Reliable Detection of Citrus tristeza virus (CTV) in Mid-Hills of Meghalaya, India. Int.J.Curr.Microbiol.App.Sci. 7(05): 1296-1300. doi: https://doi.org/10.20546/ijcmas.2018.705.157 